\title{
Recent Trends in Nepal's Foreign Policy, and Role and Functions of Our Diplomats: A Personal Viewpoint
}

\author{
Madan Kumar Bhattarai \\ Former Foreign Secretary, Government of Nepal \\ Former Ambassador of Nepal to Germany and Japan \\ Email: kutniti@gmail.com
}

\begin{abstract}
In today's world, diplomacy is considered as a basic principle in guiding the states. Since the historical era, the meaningful pursuit of diplomacy has been through the in-depth knowledge on the national determinants that signifies national goal and objectives. Actually, the foreign policy does not exist in vacuity, so the course of action to achieve the national goals of any state is only possible through diplomats having vibrant character. In Nepal, due to political instability, slow deployment process and selection of non-diplomatic persons has created diplomatic isolation. This paper identifies the modern Nepali trends in selection of competent diplomats due to the cause of political saps. This is the genuine concern to be corrected by the authority in order to enhance the essence to deploy an ideal diplomat who offers in-depth knowledge and idea about the modern diplomacy. Only, those efforts are represented through diplomats who are the image of the state. This research paper is based on descriptive study applying secondary sources of literatures as regards to modern diplomacy, international relations and foreign policy in context of Nepal and these components are analyzed to provide a clear picture of recent trends of Nepali foreign policy and functional skills of diplomats in diplomatic mission.
\end{abstract}

Key Words: Diplomacy, diplomat, foreign policy,

\section{Introduction}

"This country is a yam between two boulders. Maintain good relations with the Emperor of the North. Maintain good relations with the Emperor of the South staying overseas but he is very shrewd keeping Hindustan under his tutelage"-Prithvi Narayan Shah, architect of modern Nepal

"In archaeology, you uncover the unknown. In diplomacy, you cover the known" [Thomas Pickering Quotes. (n.d.) ]. Thomas Pickering (1931-), US Under-Secretary of State/ambassador to UN, India, Russia, Israel, Jordan and El Salvador].

"Study history, study history. In history lies all the secrets of statecraft" (Woolcock, Szreter\&Rao, 2009). Sir Winston Churchill (1874-1965), Prime Minister and scholar of United Kingdom

"If we open a quarrel between past and present, we shall find that we have lost the future". Sir Winston Churchill

"Foreign Service is the United States' first line of defense”. Dean Acheson (1893-1971), US Secretary of State

“An ambassador bears no blame”. Chinese Proverb

"Diplomacy: the business of handling a porcupine without disturbing the quills". Unknown

“...We have no eternal enemies, and we have no perpetual enemies. Our interests are eternal and perpetual and those interests it is our duty to follow..." Lord Palmerston (1784-1865), two times British Prime Minister and a long-time Foreign Secretary serving three terms 
77 | Journal of APF Command and Staff College

“...the Foreign Minister is a vehement champion of his own national interests. Indeed, his basic function is to get as much as possible for his country while giving as little as possible in return. He is more obliged than any of his colleagues to perceive his limitations of national positions and to seek legitimacy for national policies in terms of a broader ideal. Public opinions and his own colleagues are liable to make the Foreign Minister the scapegoat for the nation's inability to get its own way". Abba Eban, Statesman, diplomat, writer, scholar and Foreign Minister of Israel

"Whatever policy you may lay down, the main feature of the foreign policy of any country has to be to find out what is most advantageous to her. We may talk about international goodwill and may mean what we talk. We may talk about peace and freedom and earnestly mean what we say. But in the ultimate analysis a government functions for the good of the country it governs and no government dare do anything which in the short or long run is manifestly to the disadvantage of that country. Therefore, whether a country is imperialistic or Socialist or Communist, its Foreign Minister thinks primarily of the interests of that country. And no doubt so'.Pandit Jawaharlal Nehru (1889-1964), Prime Minister/External Affairs Minister of India 1947-64 and noted scholar

"Prime Ministership is not my profession and I would have resigned but for one thing, and that is my interest in the foreign affairs portfolio. In the field I came to know much more than anybody else in the country. And it is because I feel that by running the External Affairs Ministry I do something good and useful for the country that I have not resigned my office". Pandit Jawaharlal Nehru

The above quotations are clear and call for professional handling of foreign policy by trained people so that they can not only be conscious of their national interests but also pursue a policy taking into account international norms and practices.

Diplomacy is the art of management that uses the mechanisms of coercion and consent among the various actors of international politics (Aksoy, 2018). Diplomacy and diplomats existed long before the advent of professional. Then, the question arises as such who is diplomat? Diplomat is a person who carries out the art using his professional knowledge in international forum for the best interest of the nation. Foreign Service that was the terminology used by British diplomatist Alexander Cunningham only in the early 18th century and long before the practice of the formal institutions of foreign ministry or foreign minister came into vogue. The peace of Westphalia, the Vienna and Aixla-Chapelle congresses, two devastating world wars, the invention of nuclear weapons, the inauguration of international regimes, the disintegration of the Soviet Unions and the end of Cold War, the technological revolution and the emergence of global terrorism are just a few examples of numerous noteworthy developments evolving the phenomenon of diplomacy, and urging thinkers to make new interpretations of the concept (Aksoy, 2018). Traditional diplomats were not professionals trained in the art and culture of diplomacy but encompassed a wide variety of people. This included a whole range of dispersed, scattered, variegated and amorphous entities over the long period of years and essentially consisted of princes and family members of rulers, courtiers, soldiers, clergymen, businessmen and political people, both desired and undesired. The latter class generally meant glorious exile of some senior people who were virtually unwanted in the sending country or in a way not palatable to the ruling circles.

Clearly, for the diplomat of the 21st century, success hinges on being proficient in a multitude of areas and familiar with a variety of tools (Lindstrom, 2002, p. 18). These have now been completely replaced by professional diplomats practically all over the world. Today's more dynamic global environment means that diplomacy must pay attention to a broad range of constituencies within nations, from minor political parties to powerful corporations to the press to public interest groups 
(Kaden, 1999, p. 24; Lindstrom, 2002, p. 9). But in context of Nepal, we perhaps tend to believe more in tradition and convention in forms and semantics if not in actual substance, Nepal has continued to rely more on this rather archaic and obsolete brand of diplomacy in the form of nondiplomatic diplomats and non-professionals. It is a pity that despite claims of radical transformation in governance and even systemic changes, Nepal doles out plum and major diplomatic postings to amateurs and neophytes playing no role nor commanding any respect in the community. This has produced a powerful but disorganised vested constituency at home jockeying for positions in diplomatic postings with no apparent result or even contributing to opposite and counterproductive impact in the conduct of diplomacy.

In the world of practising diplomacy, diplomats have far greater role not only inshaping the destiny of bilateral or multilateral relations but also portraying true picture of the country they represent. As the world gets complicated and complex with changing complexions ofvarious kinds, the roles and functions of diplomats have seen marked changes even though as a subject matter, diplomacy is quite resistant to change and diplomats are asked to perform so many traditional functions apart from imbibing changing contours of modern diplomacy. Another visible revolution is taking place in the business and finance sector where a variety of indicators point to greater international activity (Lindstrom, 2002, p. 10). Even in this aspect whether in the garb of economic diplomacy, political message, remittance flow, climate change and environment, terrorism and security, strategic and military diplomacy or even inclusion, non-diplomats have been able to carve out a special niche in Nepalese diplomatic appointments with little concrete results for the country. On the other hand, entrusting non-diplomats with diplomatic jobs has led to political and diplomatic embarrassments and faux pas on many counts.

Foreign policy is truly an extension of domestic policy and can't essentially be divorced from the internal political dynamics. Though forces of continuity and change characterise foreign policy, nations have often preferred continuity and even status quo defying urge for changes that may be one answer why we hear disappointment with our foreign policy courses and decisions from internal actors. However, there can be no excuse for resorting to non-diplomatic methodology in the selection and practice of diplomats and diplomacy as if this is only typical to Nepal.

Frequent changes in the position of executive heads and foreign ministers like in Nepal have denied the much required stability in terms of formulating and executing foreign policy. Diplomatic isolation seems to be the trend in our case as political instability saps the very essence of our diplomatic efforts to enhance the image of the country not to speak of long-term engagements.

For many years, the portfolio of foreign affairs was also taken as a part-time job not necessitating a full-fledged Foreign Minister or clubbed with the post of Prime Minister as we probably thought it prudent to take cue from Pandit Jawaharlal Nehru who was his own External Affairs Minister throughout his tenure from 1947 to 1964 including his almost one year stint in the Provisional Government or Zhou Enlai who did not appoint a full-fledged Foreign Minister for almost a decade as he might have thought it more appropriate to handle the job directly.

With successful completion of elections to three tiers of government under the federal democratic order as espoused by the Constitution of Nepal 2015 and formation of a Left Alliance government under the leadership of Prime Minister K.P. Sharma Oli that took power on February 15, 2018, it is expected that Nepalese diplomacy will see a new status in terms of stability and firm footing to further national interest and promote rapid socio-economic transformation of the country. 


\section{9 | Journal of APF Command and Staff College}

The major problem in Nepal is that there are too many changes in the position of the Foreign Minister as they accompany unstable formation of governments and their changes. A cursory view of the post of Foreign Minister after its creation exactly 67 years ago shows that there have been 91 changes in the portfolio including the recent induction of the new government when Prime Minister K.P. Sharma Oli has for the time being assumed the post of Foreign Minister. The post of Foreign Secretary of Nepal is, however, both an island of stability in over-all sense except some rare exceptions. As numerouno of the Foreign Service, the post has a vital and central role in formulating and executing foreign policy. It is, however, unfortunate that the authority of the post of Foreign Secretary already not in line with that of other SAARC countries has gradually denuded with the passage of time. So far, there have been only 25 changes with 23 people assuming the role of the top official of the Ministry of Foreign Affairs (MOFA).

That there is virtual disconnect between MOFA and missions abroad is more than proved by continuing arbitrariness in the selection and posting of top and senior diplomats. It seems we have failed to draw right lessons from our own experience and that of our neighbours not to speak of general international trends. It seems we are likely to continue this course for many years to come as there is a mistaken impression in the psyche of Nepalese political class that political appointment of such posts serves its purpose better.

On the other hand, Consular positions though taken as the kernel of modern diplomacy in all countries have virtually been outsourced to other departments and ministries in Nepal as if the Ministry of Foreign Affairs (MOFA) is either incapable of handling them or relishes in relinquishment of these services. In recent years, MOFA has turned into a virtual post office, orphanage or simply a damage control switch box as one wishes to put it. In addition, the emphasis these days seems to be more on quantitative rather than qualitative growth weakening our foreign policy. No attempt has been made to utilize experience and expertise of people who have accomplished these virtues during their stints in the service. A simple example is the blunder committed by successive governments to constitute committees with majority of non-diplomats and people with vested interests to look after and suggest improvements in the service, a job primarily given to professional diplomats in other countries. It seems in many cases, such appointments have been made as a preparatory or rehearsal exercise to inducting such people for major diplomatic assignments.

\section{Review of Foreign Policy in 2014-2017}

2014 saw two major visits at bilateral levels, Prime Minister Sushil Koirala's attendance of the swearing-in of Prime Minister Narendra Modi following the resounding success achieved by the National Democratic Alliance led by the Bharatiya Janata Party under the stewardship of Mr. Modi in May 2014. The other visit of the year was the much-publicised official visit paid by Prime Minister Modi to Nepal. It was the second bilateral visit by the new Prime Minister of India to any foreign country after his taking over as the chief executive of the country. His speech in Nepalese parliament and his personal diplomacy emphasizing four Cs, cooperation, connectivity, culture and constitution, along with signing of ten agreements won the hearts and minds of the people and he became an instant celebrity in Nepal. This was also the first bilateral visit by Indian Prime Minister after a long gap of seventeen years.

Mr.Modi's visit to Nepal was preceded by the Third Meeting of the Joint Economic Commission at the level of Foreign Ministers that was pending for a very long time in July and the two sides 
expressed their determination to speed up bilateral projects and enhance mutual cooperation in several areas.

The last part of the year (November 2014) saw Nepal's hosting of the 18th SAARC Summit in Kathmandu that saw the participation of all leaders from South Asia. Prime Minister Modi again had the opportunity to visit Nepal for the second time.

The year 2015 was important in the sense that Nepal suffered colossal human and material losses as a result of mega-earthquake that hit Nepal on April 25, 2015. The international community pledged substantial aid to Nepal in the task of reconstruction during the international conference held in Kathmandu after two months of the deadly earthquake. However, it is a matter of serious selfintrospection as we have badly failed in our efforts for undertaking reconstruction and rehabilitation measures despite almost three years of dreadful tremors.

Compared to the experience of 1934 earthquake when the country had serious problems of both human and material resources including infrastructures and transport connectivity, it is unfortunate that we have not been able even to replicate what we had achieved more than eight decades ago. It may be recalled that Nepal had been able to fully reconstruct and rehabilitate the country within four and half years of the killer quake of 1934 without any outside support.

The year 2016 marked the state visit of Prime Minister K.P. Oli to India and this was followed by his official visit to China. While the visit to India was taken as a serious attempt on the part of Nepal to repair the damage inflicted on bilateral ties caused largely by disruption of supplies of essential commodities from India earlier, the visit to China proved historical in the sense that some major agreements including a transit agreement were signed during the visit. Two more visits at the level of the Prime Minister from Nepal (Pushpa Kamal Dahal 'Prachanda' and Sher Bahadur Deuba) to India also took place during the subsequent period.

Major landmarks in Nepal-India relations during 2016-17 were the exchange of state visits between the two countries. Then President Pranab Kumar Mukherji paid a State Visit to Nepal in November 2016. This was reciprocated by the State Visit undertaken by President Bidya Devi Bhandari in April 2017.

The Eminent Persons' Group composed of the representatives of the two countries constituted for the purpose of making suggestions for enhancing bilateral relations has already held seven meetings so far and the Group is expected to submit its recommendations later this year. Even in composition of the groups from the two countries, it seems Nepal has missed the opportunity with the impression that the MOFA has apparently outsourced the job unlike the case of India.

The major problem in case of Nepal's foreign policy along with other domestic functions is lack of sustained homework and failure to keep momentum on various matters that have crucial role in augmenting and reinforcing bilateral ties. A major decision in the way of expediting bilaterally agreed projects was the constitution of an oversight mechanism consisting of the Foreign Secretary of Nepal and Ambassador of India to Nepal with provision for regular monthly meetings.

That Nepal has given adequate importance to the portfolio of foreign affairs is amply proved by the fact the rank of at least one-third of deputy prime ministers in the context of a plethora of such positions in Nepal in the recent past, is allotted to those holding the position of foreign ministers. So far, at least eight people, Kirtinidhi Bista, Madhav Kumar Nepal, K.P. Sharma Oli, Kamal Thapa, Ishwar Pokhrel, Narayan Kaji Shrestha 'Prakash', Krishna Bahadur Bohara and Upendra Yadav, have held the portfolio of foreign affairs along with their senior ranks of deputy prime ministers. 


\section{1 | Journal of APF Command and Staff College}

In the first half of February 2018, a high-level task force has submitted its report on ways and means of streamlining Nepalese foreign policy. Though the report is yet to be made public, it is apparent that the task force headed by the Foreign Minister seems to have once again missed a big opportunity by not taking inputs from professionals in the foreign office as it was dominated by non-diplomats. As already said earlier, in similar situations, such reports are written by career diplomats in other countries including India and other countries in our neighbourhood.

To conclude, let us be optimistic that the new government would rise to the occasion and pave way for a professional and more pragmatic handling of Nepal's foreign affairs. It is incumbent on the MOFA to take a lead in this matter and impress on the authorities that Nepal can't remain in isolation in terms of making our foreign policy and MOFA more professional and action-oriented as there are no grounds for amateurism in foreign policy.

\section{References}

Aksoy, M. (2018). Redefining diplomacy in the 21 st century \& examining the characteristics of an ideal diplomat. MANAS Journal of Social Studies, 7 (3), 908-921. Retrieved from http://journals.manas.edu.kg/mjsr/archives/Y2018_V07_I03/d5b47c528a164911902c1b10b1 d121d8.pdf

Kaden, L., et al. (1999). America's overseas presence in the 21st Century. Washington: Overseas Presence Advisory Panel.

Lindstrom, G. (2002). Diplomats and Diplomacy for the 21 st Century. RAND Graduate School

Thomas Pickering Quotes. (n.d.). Quotes.net. Retrieved January 27, 2019, from https://www.quotes.net/quote/21087

Woolcock, M, Szreter, S. \&Rao, V. (2009).How and Why Does History Matter for Development Policy? Retrieved from https://www.cgdev.org/sites/default/files/archive/doc/events/4.21.10/Woolcock_WEB_VERS ION.pdf 